Artikel Penelitian

\title{
Rancang Bangun Mesin CNC 2 Sumbu
}

\author{
Firman Ridwan, Arif Novriheldi \\ Jurusan Teknik Mesin, Fakultas Teknik, Universitas Andalas, Padang
}

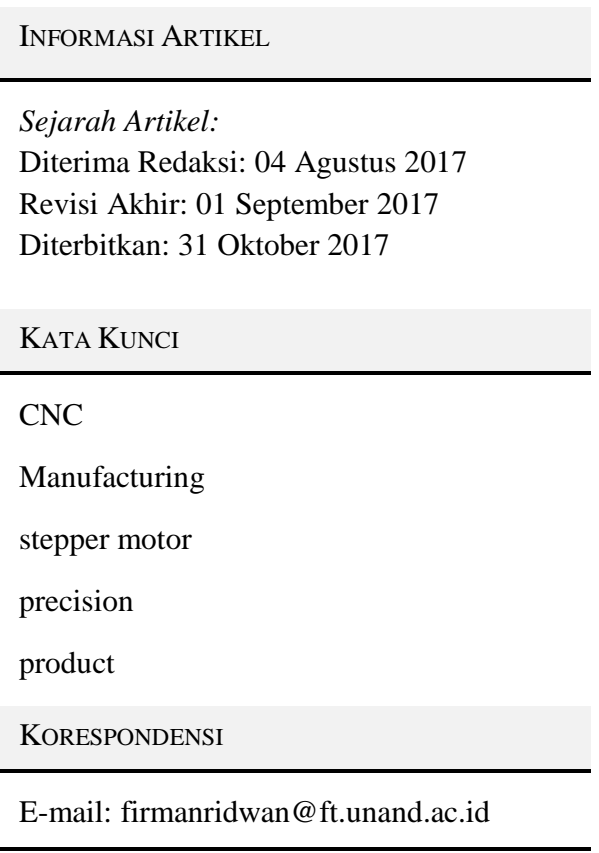

\section{A B S T R A C T}

\begin{abstract}
Nowadays, high accuracy and precision of products have become a major requirement by the manufacturer. It can only be achieved by using a controlled machine such as CNC machine. On the other hand, most of home industries have conventional production machines and manually operated. Unavailable precisian machines cause difficulties to achieve such products. In most cases, capability of home industries to buy high cost machines is limited. Therefore, it is then to be the backdrop of designing a simple construction and its control system for a low cost CNC plasma cutting machine. A low cost CNC plasma cutting machine was designed and expected to be realible in controlling the movement of the axis preciselly during cutting process. The result of this study showed that the machine was capable of achieving the following levels of precision up to $0.05 \mathrm{~mm}$ for the $\mathrm{X}$-axis with a deviation of $0.04 \mathrm{~mm}$. Meanwhile the $\mathrm{Y}$ axis was obtained up to $0.08 \mathrm{~mm}$ with a deviation of 0.057 . The results indicate that the achieved accuracy is higher compared to the manual cutting.
\end{abstract}

\section{PENDAHULUAN}

Dunia industri sedang berkembang pesat saat ini di tanah air. Perkembangan ini tak lepas dari kebutuhan konsumen yang menginginkan produkproduk dengan kualitas yang tinggi. Hal ini juga terjadi pada industri manufaktur dimana konsumen menginginkan produk dengan ketelitian dan kepresisian yang tinggi.

Ketelitian dan kepresisian yang tinggi ini dapat disuguhkan oleh workshop di industri manufaktur yang telah memiliki mesin-mesin yang handal dan bekerja secara otomatis seperti mesin dengan kontrol CNC atau Computer Numerical Controlled. Namun mesin-mesin CNC ini hanya dimiliki oleh workshop pada industri-industri besar.
Kondisi ini bertolak belakang dengan workshopworkshop kecil yang hanya memiliki mesin produksi konvensional. Mesin produksi konvensional ini memiliki ketelitian dan kepresisian yang bergantung pada kehandalan operator penggeraknya. Contohnya yaitu pada proses pemotongan baja yang selama ini menggunakan proses konvensional dan dilakukan secara manual seperti metode pemotongan dengan gas $O x y$ Acetylene. Pemotongan menggunakan meotde ini menghasilkan permukaan yang kasar dan tidak beraturan, sehingga dibutuhkan proses lanjutan untuk membentuk permukaan yang lebih halus dan sesuai desain. Namun proses tambahan ini juga dikerjakan secara manual. Jadi dapat dipastikan juga bahwa hasilnya akan tergantung pada kehandalan operatornya. 
Keterbatasan dalam hal ketelitian tersebut dapat diatatasi dengan sebuah mesin $\mathrm{CNC}$ yang digunakan untuk proses pemotongan. Namun pada umumnya workshop kecil ini mempunyai keterbatasan dalam hal biaya untuk membeli sebuah mesin CNC, karena mesin CNC komersial memiliki harga yang relatif lebih mahal dibandingkan mesin konvensional.

Hal ini kemudian melatarbelakangi pembuatan sebuah konstruksi sederhana serta sistem otomasi untuk sebuah mesin $\mathrm{CNC}$ yang nantinya dapat digunakan untuk membantu proses pemotongan plat baja. Konstruksi yang dibuat diharapkan memiliki harga yang lebih murah, namun memiliki performa yang cukup baik.

\section{METODOLOGI}

Pembuatan konstruksi dan sistem otomasi untuk mesin CNC ini melalui tiga tahapan utama, yaitu perancangan, pemilihan komponen dan perakitan. Pada proses perancangan, terdapat dua hal yang harus dirancang. Perancangan tersebut meliputi konstruksi dan elemen kontrol.

Perancangan konstruksi diawali dengan membuat desain tiga dimensi konstruksi tersebut menggunakan software Autodesk Inventor Student Edition. Pembuatan desain ini meliputi desain dari ketiga sumbu dari mesin CNC yang akan dibuat. Konstruksi yang dirancang dapat dilihat pada Gambar 1.

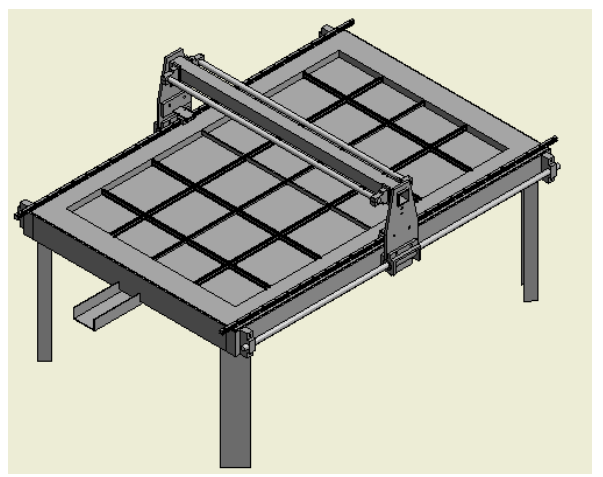

Gambar 1. Perancangan Konstruksi Mesin CNC
Setelah perancangan konstruksi didapatkan maka tahap selanjutnya adalah mengubah konstruksi tersebut kedalam bentuk nyata. Proses yang dilakukan meliputi pengelasan, proses turning dan lain-lain.

Proses selanjutnya yaitu perancangan elemen kontrol. Pada tahap ini elemen kontrol yang digunakan yaitu sebuah Personal Computer (PC), motor, driver motor dan sistem transmisi serta guide ways.

Proses selanjutnya adalah pemilihan elemen kontrol yang digunakan. Pemilihan elemen kontrol ini disesuaikan dengan kebutuhan desain konstruksi dan ketersediaan di pasar. Untuk elemen kontrol yang perlu dipersiapakan terlebih dahulu yaitu sebuah Breakout Board atau BOB. BOB diperlukan untuk membagi sinyal dari sebuah PC kepada driver masing-masing sumbu mesin CNC. Bentuk fisik dari BOB dapat dilihat pada Gambar 2.

Pada BOB terdapat sebuah parallel port dan USB port yang menghubungkan $\mathrm{BOB}$ dengan sebuah $\mathrm{PC}$. Kedua port tersebut dapat digunakan untuk menghubungkan PC dengan BOB, namun penggunaan parallel port dianjurkan dikarenakan kemudahan dalam mengatur pin-pin untuk input signal pada program pengontrol mesin CNC. Hal ini kemudian menjadi salah satu syarat penting dari sebuah PC, dimana PC yang digunakan dianjurkan memiliki sebuah parallel port.

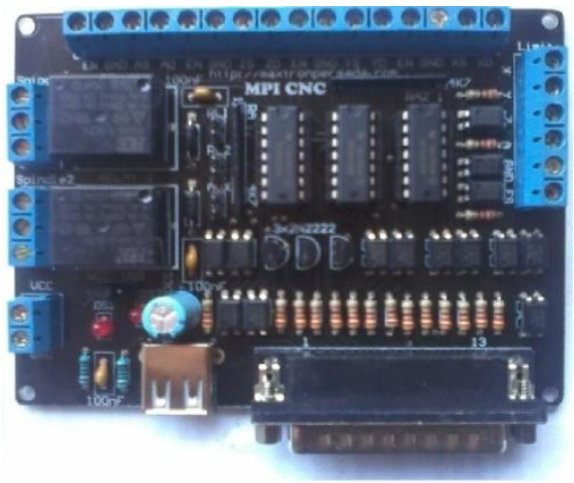

Gambar 2. Breakout Board (BOB) 
Selanjutnya yaitu pemilihan motor dan driver. Motor yang digunakan yaitu dua jenis motor stepper yang tersedia banyak di pasaran. Terdapat dua jenis motor yang digunakan dalam konstruksi ini. Perbedaan motor ini dilandasi oleh perbedaan beban yang akan diangkut oleh ketiga motor pada setiap sumbu. Sumbu y dan sumbu z memiliki beban yang lebih ringan dibandingkan dengan sumbu $\mathrm{x}$, sehingga motor sumbu $\mathrm{x}$ memiliki torsi yang lebih besar. Pada pembuatan mesin ini motor untuk sumbu y dan sumbu z yaitu motor stepper Nema 23 270oz-Inch (Gambar 3a), sedangkan untuk motor sumbu $\mathrm{x}$ digunakan motor stepper Nema 34 1200oz-Inch. (Gambar 3b).

Setelah pemilihan motor dilakukan, maka tahap selanjutnya yaitu pemilihan driver. Pemilihan driver ini dilakukan dengan menyesuaikan motor yang dipilih karena masing-masing motor memiliki spesifikasi yang berbeda. Untuk motor Nema 23 dipilih driver TB6600 (Gambar 4a), sedangkan untuk motor Nema 34 dipilih driver CW 8060 (Gambar 4b).

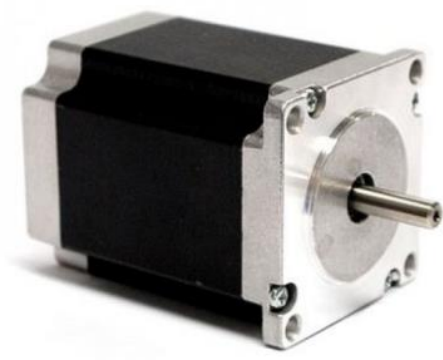

a. Nema 23 270oz-Inch

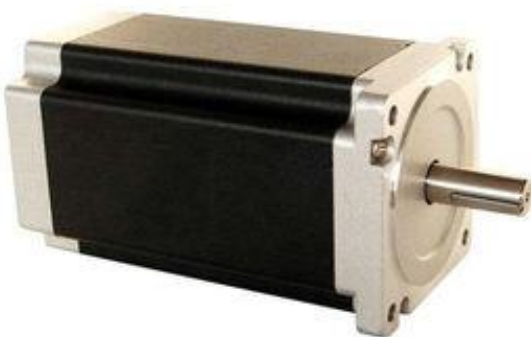

b. Nema 34 1200oz-Inch

Gambar 3. Motor Stepper untuk penggerak
Proses selanjutnya yaitu pemilihan transmisi. Transmisi digunakan untuk meneruskan daya atau putaran dari motor dan mengubah gerak rotasi motor menjadi gerak linear. Pada pembuatan mesin ini diharapkan hasil yang didapatkan memiliki ketelitian yang tinggi, sehingga digunakan ball screw sebagai transmisinya. Ballscrew adalah transmisi yang tidak mempunyai backlash, sehingga ketelitian geraknya sangat tinggi dan sesuai dengan putaran motor yang diberikan.

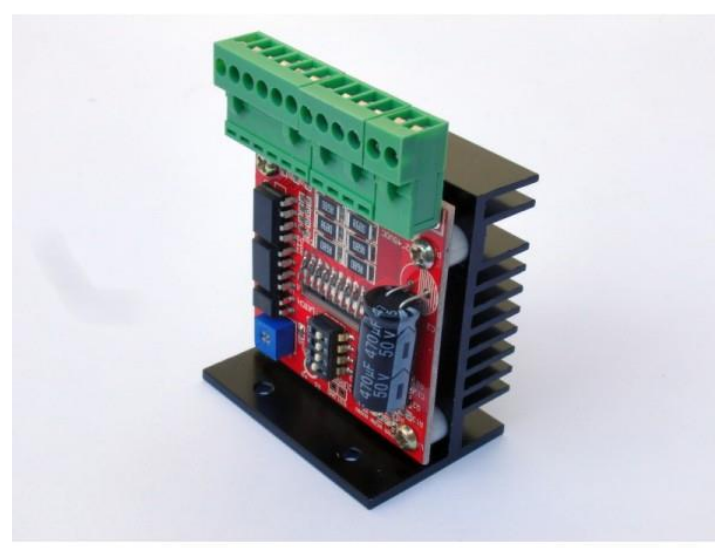

a.Driver TB 6600

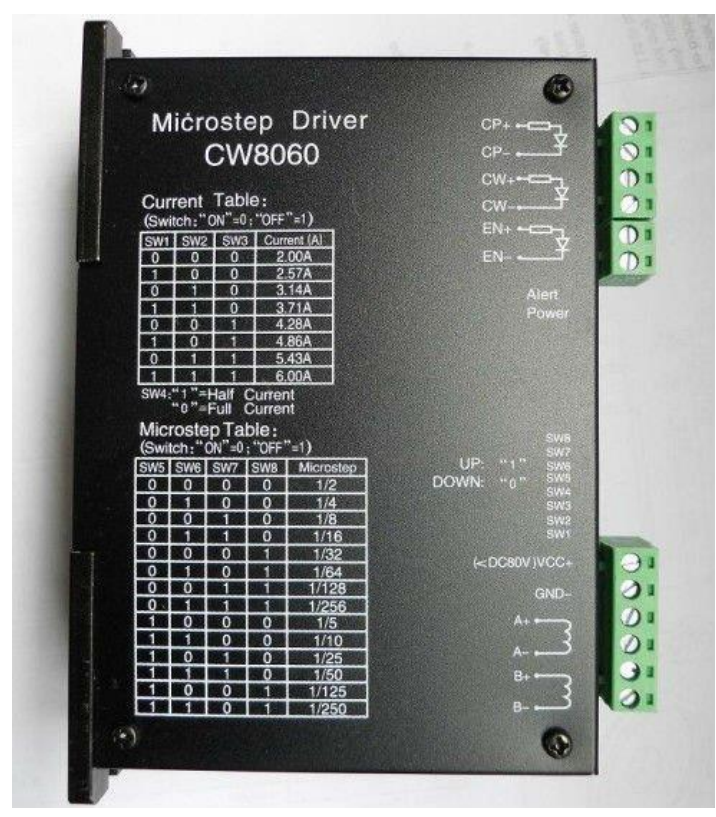

b.Driver CW 8060

Gambar 4. Driver penggerak motor stepper 
Selain transmisi dan motor juga diperlukan coupling untuk menghubungkan motor dengan batang transmisi. Pada pengerjaan konstruksi ini, seluruh proses perakitan dilakukan secara manual, sehingga memungkinkan adanya miss alignment antara motor dan transmisi. Untuk mengatasinya, digunakan flexible couping yang dapat mentolerir miss alignment tersebut.

Setelah pemilihan transmisi dilakukan, maka tahapan selanjutnya yaitu pemilihan slider. Slider berfungsi untuk mengarahkan gerak mesin pada setiap sumbu nya. Pada mesin ini digunakan dua buah linear bearing pada sumbu $x$ dan sumbu y serta sebuah silinder pejal sebagai jalunya. Pemilihan linear bearing dilakukan karena kemudahan dalam mendapatkannya di pasaran dan harganya yang relatif lebih murah.

Setelah semua komponen didapatkan, maka dilakukan perakitan semua komponen. Untuk elemen seperti driver dan BOB, perakitan yang dilakukan adalah seperti yang dpat dilihat pada Gambar 5.

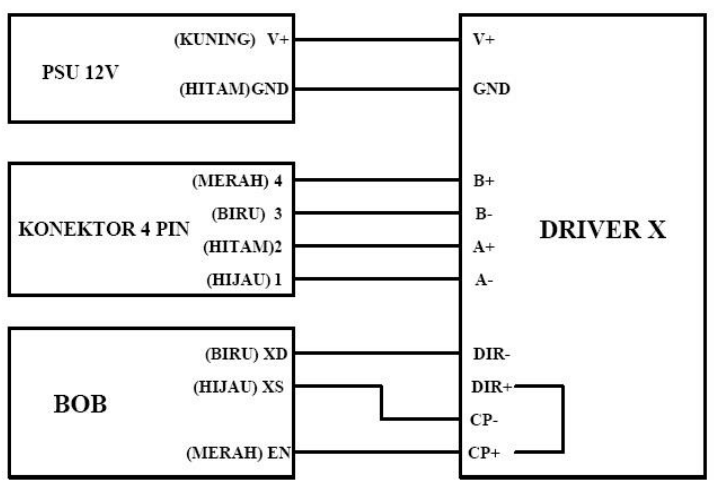

Gambar 5. Konfigurasi Wiring Driver, BOB dan Motor Stepper

Untuk perakitan konstruksi dapat dilihat pada Gambar 6.

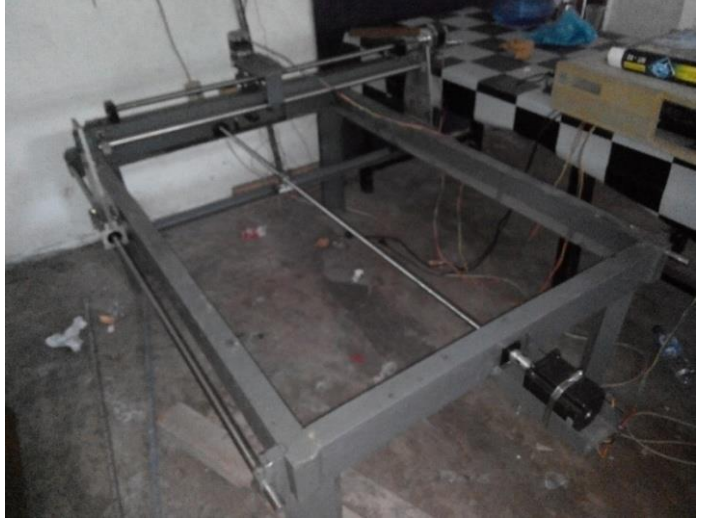

Gambar 6. Konstruksi Mesin CNC

\section{HASIL DAN PEMBAHASAN}

Setelah pembuatan mesin dilakukan, diperlukan parameter untuk benda kerja yang dapat dikerjakan oleh mesin. Untuk area kerja tersebut ditinjau dari masing-masing sumbu yaitu:

Area kerja dalam sumbu $\mathrm{x}=$ Panjang meja kerjalebar slider sumbu $\mathrm{x}$

$$
=150 \mathrm{~cm}-15 \mathrm{~cm}
$$$$
=135 \mathrm{~cm}
$$

Area kerja dalam sumbu y $=$ Jarak antar bearing panjang $n u t$

$=87 \mathrm{~cm}-4 \mathrm{~cm}$

$=83 \mathrm{~cm}$

Area kerja dalam sumbu $\mathrm{z}=$ Panjang linear guide-panjang nut sumbu $\mathrm{Z}$

$=10 \mathrm{~cm}-3 \mathrm{~cm}$

$=7 \mathrm{~cm}$

Setelah didapatkan area kerja masing-masing sumbu maka dilakukan pengaturan transmisi. Pengaturan transmisi ini dilakukan untuk mengatur jumlah putaran motor yang diperlukan agar mesin bergerak sejauh jarak yang diinginkan. Untuk pengaturan tersebut dibutuhkan data sebagai berikut:

- Sumbu X

$\begin{array}{ll}\text { Motor Stepper } & =1,8 \mathrm{deg} / \mathrm{step} 5 \text { Ampere } \\ \text { Pitch ball screw } & =5 \mathrm{~mm} \\ \text { Microstep } & =1 / 8 \text { subdivision }\end{array}$


- Sumbu Y

Motor Stepper $\quad=1,8 \mathrm{deg} / \mathrm{step} 3$ Ampere

Pitch ball screw $\quad=5 \mathrm{~mm}$

Microstep $\quad=1 / 8$ subdivision

- Sumbu Z

$$
\begin{array}{ll}
\text { Motor Stepper } & =1,8 \mathrm{deg} / \mathrm{step} 3 \text { Ampere } \\
\text { Pitch ball screw } & =10 \mathrm{~mm} \\
\text { Microstep } & =1 / 8 \text { subdivision }
\end{array}
$$

Setelah mengetahui beberapa parameter tersebut, nilai yang akan dimasukkan pada motor tuning dapat dihitung dengan mencari step per revolution dan step per unit. Berikut persamaan untuk menghitung step per revolution dan step per unit:

\section{a. Step per revolution}

Persamaan:

$\frac{360 \text { degree }}{1 \text { revolution }} \times \frac{\text { step }}{\text { degree }}=\frac{\text { step }}{\text { revolution }}$

b. Step per unit

Persamaan:

$\frac{\text { revolution }}{\text { pitch }(\mathrm{mm})} \times \frac{1}{\text { microstep }} \times \frac{\text { step }}{\text { revolution }}=\frac{\text { step }}{\text { unit }(\mathrm{mm})}$

Dari persamaan tersebut, dapat dihitung step per unit. Hasil perhitungan step per unit pada setiap sumbu dapat dilihat pada Tabel 1.

Tabel 1. Tabel Data Konfigurasi Motor Tuning

\begin{tabular}{|l|r|r|r|r|r|}
\hline Sumbu & $\begin{array}{c}\text { Deg/ } \\
\text { step }\end{array}$ & $\begin{array}{c}\text { Step / } \\
\text { revolution }\end{array}$ & Pitch (mm) & $\begin{array}{c}\text { Micro } \\
\text { step }\end{array}$ & $\begin{array}{c}\text { Step / unit } \\
(\mathrm{mm})\end{array}$ \\
\hline $\mathrm{X}$ & 1.8 & 200 & 5 & 0.13 & 320 \\
\hline $\mathrm{Y}$ & 1.8 & 200 & 5 & 0.13 & 320 \\
\hline $\mathrm{Z}$ & 1.8 & 200 & 10 & 0.13 & 160 \\
\hline
\end{tabular}

Nilai yang didapat pada Tabel 1 selanjutnya dimasukkan ke dalam pengaturan motor tuning pada Mach 3 pada setiap sumbu seperti yang dapat dilihat pada Gambar 7.

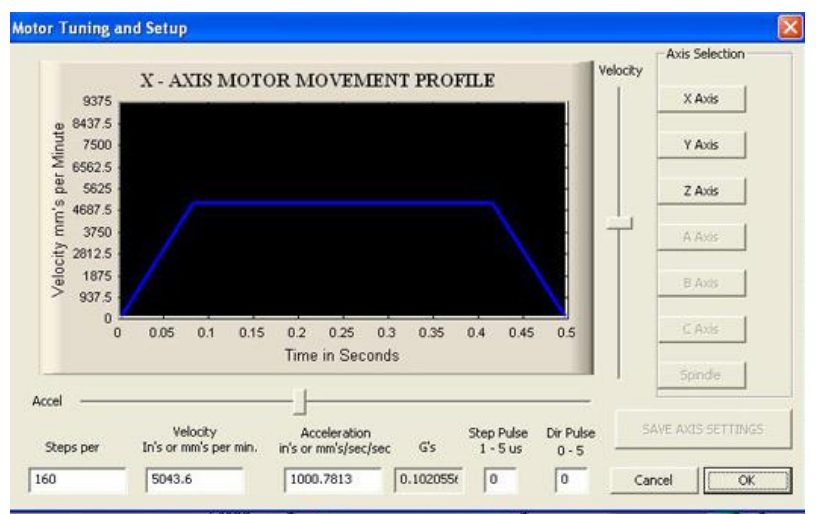

Gambar 7. Mach 3 Motor Tuning and Setup

Setelah pengaturan motor tunning, kemudian dilakukan pengaturan lainnya seperti input signal dan output signal. Pengaturan ini disesuaikan dengan pin yang digunakan pada BOB.

Tahapan selanjutnya yaitu pengujian kinerja mesin. Pengujian yang dilakukan memiliki tiga tujuan, yaitu untuk mengetahui ketelitian mesin, untuk mengetahui kepresisian mesin dan untuk mengetahui kinerja mesin saat membentuk geometri yang lebih rumit.

Pengujian diawali dengan membuat gambar pada AutoCAD. Skema pengujian ketelitian dapat dilihat pada Gambar 8, sedangkan untuk pengujian kepresisian persegi dapat dilihat pada Gambar 9a sedangkan pengujian kepresisian lingkaran dapat dilihat pada Gambar 9b.

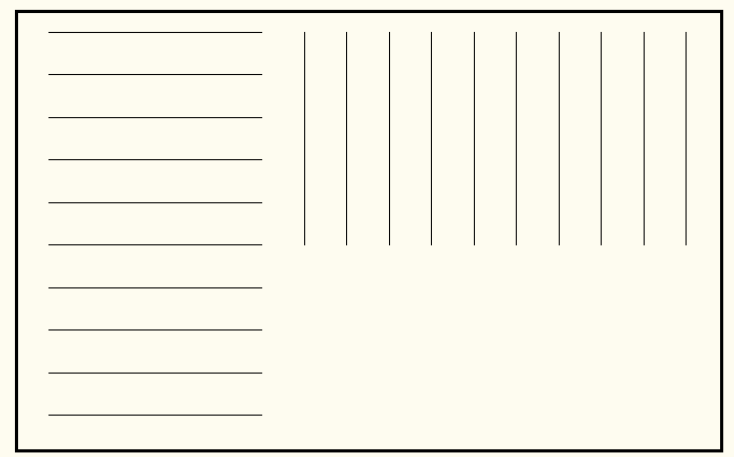

Gambar 8. Desain Sampel Pengujian Ketelitian 


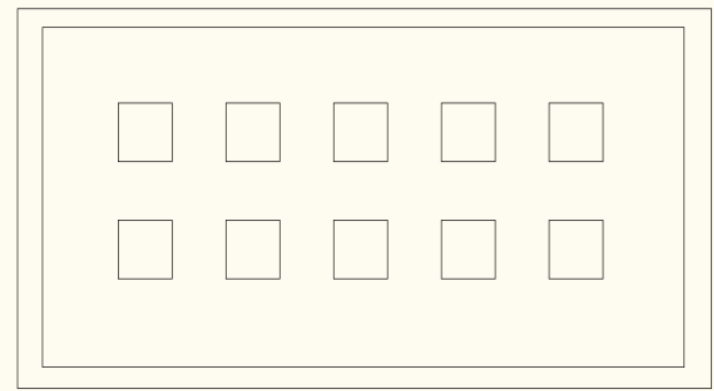

a. Keterulangan persegi

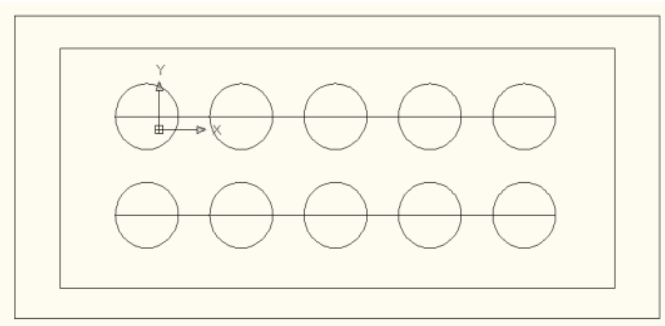

b. Keterulangan lingkaran

\section{Gambar 9. Desain Sampel}

Gambar sampel pengujian selanjutya diubah menjadi G-Code melalui program MasterCAM. Setelah G-Code didapatkan, maka G-code tersebut dimuat kedalam Mach3. Tahap selanjutnya G-Code tersebut dieksekusi untuk melihat kinerja mesin. Pada Gambar 10 diperlihatkan hasil pengujian ketelitian sumbu $\mathrm{x}$ dan y serta keterulangan persegi.

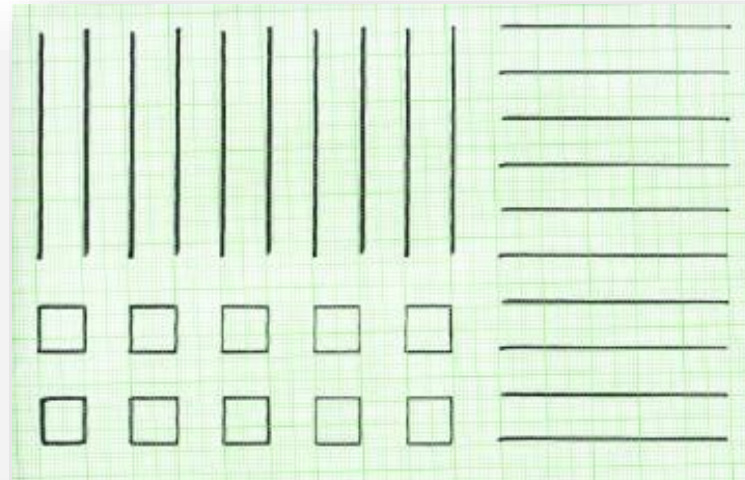

Gambar 10. Hasil pengujian ketelitian sumbu x dan y Serta keterulangan persegi

Dari pengujian yang telah dilakukan didapatkan gambar yang memperlihatkan tool path atau lintasan tool yang akan dipasang pada mesin ini.
Langkah selanjutnya yaitu mengukur gambar yang didapatkan untuk mengetahui performa dari mesin yang telah dibuat.

Pengukuran pertama-tama dilakukan untuk melihat ketelitian alat. Ketelitian adalah kesesuaian nilai yang didapatkan dari pengukuran dengan nilai yang diberikan pada desain. Maka dari itu perhitungan dilakukan dengan mencari standar deviasi dari nilai terukur terhadap nilai pada desain. Pengujian ketelitian dilakukan untuk melihat ketelitian pada setiap sumbu. Pada Tabel 2 dan Tabel 3 diperlihatkan hasil pengujian ketelitian sumbu $\mathrm{x}$ dan sumbu y.

Tabel 2. Hasil pengujian ketelitian sumbu x

\begin{tabular}{|r|r|r|r|r|r|r|}
\hline No & $\begin{array}{r}\text { Ukuran } \\
\text { Desain } \\
(\mathrm{mm})\end{array}$ & $\begin{array}{r}\text { Ukuran } \\
\text { Sampel } \\
(\mathrm{mm})\end{array}$ & $\begin{array}{c}\text { penyimpangan } \\
(\mathrm{x})(\mathrm{mm})\end{array}$ & $\begin{array}{c}\text { Rata-Rata } \\
\text { Penyimpangan } \\
\left(\mathrm{x}_{\mathrm{r}}\right)(\mathrm{mm})\end{array}$ & $\left(\mathrm{x}-\mathrm{x}_{\mathrm{r}}\right)(\mathrm{mm})$ & $\left(\mathrm{x}-\mathrm{x}_{\mathrm{r}}\right)^{2}(\mathrm{~mm})$ \\
\hline 1 & 50 & 49.98 & -0.02 & -0.052 & 0.032 & 0.001024 \\
\hline 2 & 50 & 50 & 0 & -0.052 & 0.052 & 0.002704 \\
\hline 3 & 50 & 49.9 & -0.1 & -0.052 & -0.048 & 0.002304 \\
\hline 4 & 50 & 49.92 & -0.08 & -0.052 & -0.028 & 0.000784 \\
\hline 5 & 50 & 49.92 & -0.08 & -0.052 & -0.028 & 0.000784 \\
\hline 6 & 50 & 50 & 0 & -0.052 & 0.052 & 0.002704 \\
\hline 7 & 50 & 49.9 & -0.1 & -0.052 & -0.048 & 0.002304 \\
\hline 8 & 50 & 49.94 & -0.06 & -0.052 & -0.008 & $6.4 \mathrm{E}-05$ \\
\hline 9 & 50 & 49.92 & -0.08 & -0.052 & -0.028 & 0.000784 \\
\hline 10 & 50 & 50 & 0 & -0.052 & 0.052 & 0.002704 \\
\hline \multicolumn{7}{|r|}{} \\
\hline
\end{tabular}

Tabel 3. Hasil Pengujian Ketelitian Sumbu y

\begin{tabular}{|r|r|r|r|r|r|r|}
\hline No & $\begin{array}{r}\text { Ukuran } \\
\text { Desain } \\
(\mathrm{mm})\end{array}$ & $\begin{array}{r}\text { Ukuran } \\
\text { Sampel } \\
(\mathrm{mm})\end{array}$ & $\begin{array}{c}\text { penyimpangan } \\
(\mathrm{y})(\mathrm{mm})\end{array}$ & $\begin{array}{c}\text { Rata-Rata } \\
\text { Penyimpangan } \\
\left(\mathrm{y}_{\mathrm{r}}\right)(\mathrm{mm})\end{array}$ & $\left(\mathrm{y}-\mathrm{y}_{\mathrm{r}}\right)(\mathrm{mm})$ & $\left(\mathrm{y}-\mathrm{y}_{\mathrm{r}}\right)^{2}(\mathrm{~mm})$ \\
\hline 1 & 50 & 49.96 & -0.04 & -0.068 & 0.028 & 0.000784 \\
\hline 2 & 50 & 49.98 & -0.02 & -0.082 & 0.062 & 0.003844 \\
\hline 3 & 50 & 49.9 & -0.1 & -0.082 & -0.018 & 0.000324 \\
\hline 4 & 50 & 49.9 & -0.1 & -0.082 & -0.018 & 0.000324 \\
\hline 5 & 50 & 49.9 & -0.1 & -0.082 & -0.018 & 0.000324 \\
\hline 6 & 50 & 49.82 & -0.18 & -0.082 & -0.098 & 0.009604 \\
\hline 7 & 50 & 49.92 & -0.08 & -0.082 & 0.002 & $4 \mathrm{E}-06$ \\
\hline 8 & 50 & 50 & 0 & -0.082 & 0.082 & 0.006724 \\
\hline 9 & 50 & 49.94 & -0.06 & -0.082 & 0.022 & 0.000484 \\
\hline 10 & 50 & 50 & 0 & -0.082 & 0.082 & 0.006724 \\
\hline \multicolumn{7}{|r|}{5} \\
\hline
\end{tabular}

Setelah ketelitian didapatkan maka dilakukan pengukuran kepresisian atau keterulangan. Keterulangan (repeatability) adalah kemampuan mesin untuk membuat produk dengan bentuk dan dimensi yang sama dari proses produksi yang dilakukan secara berulang. Pada penelitian ini, 
Tabel 4. Hasil Pengujian Keterulangan Persegi

\begin{tabular}{|c|c|c|c|c|c|c|c|c|c|}
\hline No & $\begin{array}{c}\text { Sisi X } \\
(\mathrm{mm})\end{array}$ & $\begin{array}{l}\text { Sisi Y } \\
(\mathrm{mm})\end{array}$ & $\begin{array}{c}\text { Ukura } \\
n \\
\text { Desain } \\
x \text { dan y }\end{array}$ & $\begin{array}{l}\text { penyimpangan } \\
(\mathrm{x})(\mathrm{mm})\end{array}$ & $\begin{array}{l}\left(x-x_{r}\right) \\
(m m)\end{array}$ & $\begin{array}{l}\text { penyimpang } \\
\text { an }(\mathrm{y})(\mathrm{mm})\end{array}$ & $\begin{array}{l}\left(y-y_{r}\right) \\
(m m)\end{array}$ & $\begin{array}{c}(x- \\
\left.x_{r}\right)^{2}(m m)\end{array}$ & $\begin{array}{l}\left(y-y_{r}\right)^{2} \\
(m m)\end{array}$ \\
\hline 1 & 9.92 & 9.9 & 10 & -0.08 & -0.026 & -0.1 & -0.052 & 0.000676 & 0.01 \\
\hline 2 & 10 & 9.9 & 10 & 0 & 0.054 & -0.1 & -0.052 & 0.002916 & 0.01 \\
\hline 3 & 9.98 & 9.98 & 10 & -0.02 & 0.034 & -0.02 & 0.028 & 0.001156 & 0.0004 \\
\hline 4 & 9.94 & 9.92 & 10 & -0.06 & -0.006 & -0.08 & -0.032 & 0.000036 & 0.0064 \\
\hline 5 & 9.92 & 10 & 10 & -0.08 & -0.026 & 0 & 0.048 & 0.000676 & 0 \\
\hline 6 & 9.98 & 9.94 & 10 & -0.02 & 0.034 & -0.06 & -0.012 & 0.001156 & 0.0036 \\
\hline 7 & 9.92 & 10 & 10 & -0.08 & -0.026 & 0 & 0.048 & 0.000676 & 0 \\
\hline 8 & 10 & 10 & 10 & 0 & 0.054 & 0 & 0.048 & 0.002916 & 0 \\
\hline 9 & 9.96 & 9.98 & 10 & -0.04 & 0.014 & -0.02 & 0.028 & 0.000196 & 0.0004 \\
\hline 10 & 9.84 & 9.9 & 10 & -0.16 & -0.106 & -0.1 & -0.052 & 0.011236 & 0.01 \\
\hline \multicolumn{4}{|c|}{ Rata-Rata } & -0.054 & & -0.048 & & & \\
\hline \multicolumn{8}{|c|}{ Jumlah } & 0.02164 & 0.0408 \\
\hline
\end{tabular}

pengujian keterulangan dilakukan dengan membuat bentuk-bentuk sederhana. Tujuannya adalah agar hasil yang didapatkan mudah untuk dilakukan pengukuran. Pada Tabel 4 dan Tabel 5 diperlihatkan hasil keterulangan persegi dan lingkaran.

Tabel 5. Hasil Pengukuran Keterulangan Lingkaran

\begin{tabular}{|r|r|r|r|r|c|}
\hline No & $\begin{array}{c}\text { Diameter } \\
\text { Desain } \\
(\mathrm{mm})\end{array}$ & $\begin{array}{r}\text { Diameter } \\
\text { Terukur } \\
(\mathrm{mm})\end{array}$ & $\begin{array}{c}\text { Penyimpangan } \\
(\mathrm{d})(\mathrm{mm})\end{array}$ & $\begin{array}{c}\left(\mathrm{d}-\mathrm{d}_{\mathrm{r}}\right) \\
(\mathrm{mm})\end{array}$ & $\begin{array}{c}(\mathrm{d}-\mathrm{dr})^{2} \\
(\mathrm{~mm})\end{array}$ \\
\hline 1 & 50 & 49.92 & 0.08 & 0.034 & 0.001156 \\
\hline 2 & 50 & 49.96 & 0.04 & -0.006 & 0.000036 \\
\hline 3 & 50 & 49.88 & 0.12 & 0.074 & 0.005476 \\
\hline 4 & 50 & 49.92 & 0.08 & 0.034 & 0.001156 \\
\hline 5 & 50 & 49.92 & 0.08 & 0.034 & 0.001156 \\
\hline 6 & 50 & 50 & 0 & -0.046 & 0.002116 \\
\hline 7 & 50 & 49.96 & 0.04 & -0.006 & 0.000036 \\
\hline 8 & 50 & 50 & 0 & -0.046 & 0.002116 \\
\hline 9 & 50 & 50 & 0 & -0.046 & 0.002116 \\
\hline 10 & 50 & 49.98 & 0.02 & -0.026 & 0.000676 \\
\hline \multicolumn{7}{|c|}{ Rata-Rata } & 0.046 & & \\
\hline \multicolumn{7}{|c|}{ Jumlah } & & 0.01604 \\
\hline
\end{tabular}

Pengujian selanjutnya yaitu untuk melihat kemampuan mesin mengerjakan geometri yang lebih rumit. Untuk itu dibuat sebuah pengujian keterulangan bentuk plakat roda gigi. Hasil yang didapatkan tidak diukur namun hanya dibandingkan secara kasat mata. Untuk hasil pengujian keterulangan bentuk plakat roda gigi dapat dilihat pada Gambar 11.

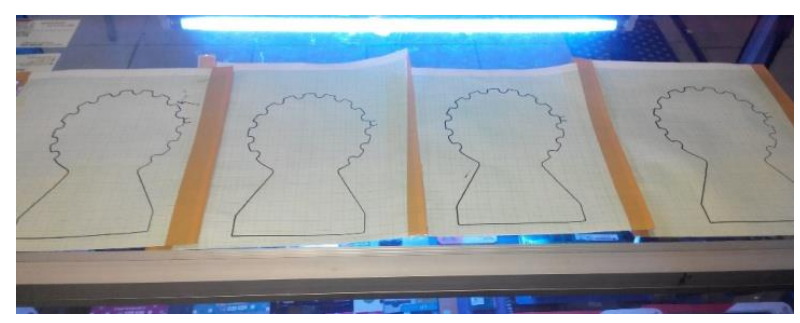

Gambar 11. Hasil Pengujian Keterulangan Plakat Roda Gigi

Dari hasil pengujian terhadap bentuk plakat roda gigi dapat dilihat bahwa mesin mampu memberikan hasil yang seragam pada pembuatan berulang. Dengan demikian dapat disimpulkan bahwa mesin memiliki keterulangan yang baik dengan bentuk yang lebih rumit.

\section{KESIMPULAN}

Dari keseluruhan pembuatan konstruksi dan sistem otomasi untuk mesin $\mathrm{CNC}$ ini dapat diambil beberapa kesimpulan sebagai berikut: (1) Telah dihasilkan sebuah konstruksi sederhana serta sistem otomasi untuk mesin CNC yang dapat bekerja sesuai dengan fungsi yang diinginkan. (2) Karakteristik dari mesin yang dihasilkan dapat 
dilihat dari pengujian toolpath yang telah dilakukan.

Hasil pengujian yang telah dilakukan adalah:

a. Pengujian Ketelitian

Ketelitian sumbu X $\quad: 0,05 \mathrm{~mm}$

Standar deviasi sumbu $\mathrm{X} \quad: 0,04$

Ketelitian Sumbu Y $\quad: 0,08 \mathrm{~mm}$

Standar deviasai sumbu Y : 0,057

b. Pengujian Keterulangan

- Persegi

Standar deviasi keterulangan sisi sumbu X: 0,049

Standar deviasi keterulangan sisi sumbu Y: 0.067

- Lingkaran

Standar Deviasi keterulangan lingkaran: 0,04

\section{DAFTAR PUSTAKA}

[1] J. Medison. CNC Machining Handbook. Industrial Press INC: New York, 1996.

[2] S. F. Krar, A. R. Gill. Technology of Machine Tool, Seventh Edison, Mc.Graw Hill International Edition, 2010.

[3] D. W. Jones. Control of stepping motor, M Mc.Graw Hill International Edition, 2001.

[4] W. H. Yeahdon. Control of small Electric Motor, Mc.Graw Hill International Edition, 2001.

[5] X. Xu, and S. T. Newman. "Making CNC machine tools more open, interoperable and intelligent - a review of the technologies," Computers in Industry, Vol. 57, No. 2, pp. 141152, 2006.

[6] S. H. Suh, D. H. Chung, B. E. Lee, J. H. Cho, S. U. Cheon, H. D. Hong, dan H. S. Lee. "Developing an integrated STEP - compliant CNC prototype", Journal of Manufacturing Systems, Vol. 21, No. 5, pp. 350-362, 2002.

[7] $\mathrm{X} . \mathrm{Xu}$, dan Q. He. "Striving for a total integration of CAD, CAPP, CAM and CNC," Robotics and Computer-Integrated Manufacturing, Vol. 20, No. 2, pp. 101-109, 2004. 